\title{
Towards a better epidemic
}

\author{
Tony Delamothe deputy editor, The BMJ
}

The consensus seems to be that no one had a particularly good Ebola epidemic, with the exception of the charity Médecins Sans Frontières (MSF). This begs the question of who makes these judgment calls, and what was the last "good" epidemic you can remember?

The World Health Organization got it in the neck for delivering too little, too late, and its own report last week joined in the criticisms, listing lessons learnt and actions planned (doi:10. 1136/bmj.h2144). MSF thought the problems went wider than WHO. The international response had been a "global coalition of inaction," its report concluded (doi:10.1136/bmj.h1619). "For the Ebola outbreak to spiral this far out of control required many institutions to fail," said its director. MSF also noted that the affected countries hadn't always made the right choices-not easy for some of the poorest countries on earth.

In The BMJ Christian Gericke continues the generally critical line, saying that the epidemic attracted medical ethics commentators "like bees to a honey pot" (doi:10.1136/bmj. h2105). Were they of any use? He thinks that the short term use of experimental drugs (and their complex ethical challenges) attracted far more attention than it deserved and distracted from the urgent business of controlling the epidemic. He quotes approvingly the bioethicist Udo Schüklenk's criticism of WHO's recommendation to provide access to experimental drugs as "pointless grandstanding in the face of a pandemic that requires a public health response."

In her feature this week Sophie Arie considers WHO's support of clinical trials for experimental drugs as a bottle half full rather than empty (doi:10.1136/bmj.h1938). A year after the first case of Ebola virus disease was reported, several phase II and III trials of vaccines and other treatments are under way- "a process that normally can take as long as 10 years was compressed into a year."
At least a dozen other neglected infectious disease pathogens have the potential to pose a similar threat to Ebola, and Arie describes how an international group of scientists has argued for fast tracking experimental vaccines and treatments for these, so that they're available at the beginning of a disease outbreak. Such long range thinking comes as a welcome alternative to the attention deficit that usually afflicts the disasterazzi, as they flit from one trouble spot to the next.

Closer to home, Kim Holt discusses two recent reports on whistleblowing in the NHS (doi:10.1136/bmj.h2300). She quotes a shocking sentence from Anthony Hooper's review into the General Medical Council's handling of cases involving whistleblowers: "An employer might use the process of making an allegation to the GMC about a doctor's fitness to practise as an act of retaliation against a doctor because he or she raised concerns, or, simply, as an inappropriate alternative to dealing with the matter in house."

So, is this grounds for abandoning the NHS to its sorry fate and heading for the private sector?

Not if you're cardiologist John Dean, who explains why he's renounced private practice (doi:10.1136/bmj.h2299). He concludes: "Perhaps the rulers of healthcare should draw an uncrossable line between private and public medicine and tell doctors to choose." Many readers will hope that such an action falls a long way down the list of the priorities of the new secretary of state for health (whose identity was unknown as this article went online).

Competing interest: My wife works in both the NHS and the private sector.

Cite this as: BMJ 2015;350:h2419

๑ BMJ Publishing Group Ltd 2015 